\section{THE PAST THAT DOES NOT LET GO... A FEW WORDS ABOUT CULTURAL STUDIES OF MAYA}

\section{Valentin A. Zubarev}

\title{
Abstract
}

$\mathrm{T}$ The research is of great interest due to the overall situation in the history of the an-cient American civilizations, to the growing interest in religion, mythology, and the worldview of pre-Columbian inhabitants of America.

Before the arrival of Europeans, the people on the unknown territory developed in their own special way. This fact is of particular interest as they didn't feel the influence of other cultures and civilizations. The people did not adopt the experience of other nations. Their life, culture, writing, architecture, painting were unique and had no analogues. This isolation allows us to recreate and analyzes the way of evolution and the development of thinking.

Also, here we have a huge, slightly unexplored cultural layer. The process of «discov-ery of America» has begun recently. It continues up to now. The Maya writing was deci-phered in the mid-twentieth century by the Soviet scientist-linguist Knorozov. In the selva of the Yucatan, the lost Maya cities were discovered almost every year.

Key words: Mesoamerica; Maya; Ancient civilization; Pre-Columbian.

Зубарев В. А.

ПІРОШЛЛОЕ,

КОТОРОЕ НЕ ПРОХОДИТ...

НЕСКОЛЬКО СЛОВ

О КУЛЬТУРОЛОГИИ МАЙЯ
The Mayan culture is considered to be the most developed of all existing ones on the American continents. It is a logical extension of the Olmec and Toltec traditions. The magnificent palaces and pyramids, developed political and military hierarchy, their polytheistic world view which represented a complex system, hieroglyphic writing, literature, folklore and science, music and ritual games were typical for the Mayans.

These are perhaps the main aspects that make up the backbone of the culture. It was said a lot as far as each item is concerned. Hundreds of works were written by foreign researchers as well as native ones. But when we discuss the culture of certain people we do not mean mythology or architecture apart. In fact the literature is linked to mythological scenes. Most architectural monuments have a religious meaning. Writing reflects the achievements of science and history.

The phenomenon of the civilization of Maya is that the people in their development were not influenced by other cultures. Being in a certain cultural incubator it evolved independently from the very beginning. If the civilization developed in isolation, we should estimate the achievements of it in a different way. It is impossible to apply Greek or any other ancient state templates.

The Mayan architecture, for example, as well as the other of Central America was characterized by stepped pyramids with truncated apex with a small temple on the top. A wide staircase with steep steps was on the way from the foot of the pyramid to the door of the temple. There were large pyramids stairs on four sides. Stairs stretched from foot to apex without a breach of continuity or from ledge to ledge. Another type of construction, conventionally called "palaces", was a narrow, elongated building divided into several rooms inside. Palaces were also artificially raised platform, but their height was much less the pyramids. If the pyramids were religious 
buildings then the «palaces» were likely to serve dwellings for the nobility and priests.

Temples and palaces were decorated with ornaments and bas-reliefs of mythological themes. Stelae (stone slabs) with plotted images of people should be noted as well as the hieroglyphic inscriptions and dates. The American scientist of Russian origin - Tatiana Proskuryakova made the breakthrough in the study of the history of the ancient Maya. [5, p. 240] M. Coe referred that Proskuryakova had analyzed inscriptions of 35 monuments of the "city» Piedras Negras marked with Mayan calendar dates. She found out that there was a definite regularity in disposition of such monuments located in front of architectural structures. All monuments formed seven stand-alone groups. Calendar stele dates matched average life expectancy. On this basis they assumed that each group represented Chronicle of a certain reign. Nowadays there are a number of facts supporting the theory. On the first monument of each group a figure of a young man sitting in a niche above the platform or plinth was depicted. Two important calendar dates were carved usually on a stele. One of them with added hieroglyph in the form of an animal's head with a bandaged cheek pointed to the time of arrival of this character to power; the other accompanied by hieroglyph of a frog with raised legs pointed to the time of birth of that man. Older monuments of the same group probably were linked with events such as marriage and the birth of heirs. Tatiana Proskuryakova was able to identify the signs associated with the names and titles, especially with the names and titles of the female characters which stood out in the classical era of the Maya sculpture. References to military victories especially if the governor had managed to seize an important enemy were on stelae [2, pp. 229-236]. Later after deciphering Maya writing by Knorozov Proskuryakova's theory received irrefutable proof.

All areas of the Maya art are interlaced. It is impossible to understand the meaning of the sacred ball game not knowing the rituals for the sake of competitions were held. Ritual can't be comprehended without understanding their world view, known as the subject of study artworks, including literature. In order to understand the meaning of their art one has to learn the mythology and religion. The level of science is estimated after reading texts, but to read texts means to be acquainted with the script.

The study of Mesoamerica is a very lively and interesting theme. Almost every year Americanists of different countries make discoveries to revise our understanding of culture and sometimes facts as far as this region is concerned. Here a few examples are. According to archaeologists' points of view (Willie G. and Bullard W., 50-th of the XX century) settlement of the classical period were "ceremonial centers" where only priests lived. The lower levels of the settlement hierarchy were represented by smaller «ceremonial centers» and villages. The bulk of the population lived there. In Gulyaev's book published in 1979 [3], the author examines the structure and functions of the city in the early class society. Here he cites Willie's study where the archaeologist indicates that there are three types of settlements: "The first one (type "A") was a ritual center surrounded by residential buildings. They were arranged so closely that their inhabitants could not engage in agriculture on the remaining vacant lots. The second type ("B") was distinguished by the fact that there was a ritual center in front of us. It had no dwelling. The houses were widely scattered throughout the neighborhood. The third type ("C") was similar to the second one ("B") so as there were no ordinary people in the ritual center. And farmers supporting the center were concentrated in villages and towns having their own minor ceremonial centers of small scale» [3, p. 164]. Pay attention: it took Willie less than 30 years to add new details to his investigations which were of great importance.

In journal «Science» (15 $5^{\text {th }}$ of September 2006) a group of authors published an article "Oldest Written in the New World». It was about the archaeological discovery known as «Cascajal block». Symbols of this block looked like the Maya hieroglyphic texts. Block dated back from 900 BC. Scientists believe that they have the sample of Epi-Olmec script which apparently is the ancestor of the Maya writing. If the authenticity of the block is confirmed, the history textbooks will have to make adjustments [5, pp. 1610-1614].

One more example: on the $11^{\text {th }}$ of July 2013 workers found the ruins of an ancient settlement 
in the municipality Jaltipan (eastern state of Veracruz). A twelve meter pyramid was excavated among other things by archeologists. The age of settlement is about 2000 years. It was the first stone pyramid detected in this region [1].
Thus, the information obtained from the books of $60-70$ years of XX century must be specified. And the data of the books of earlier editions should be checked.

\section{REFERENCIES:}

1. 2, ooo - Year Old Pyramid and Multiple Pre-Columbian Burial Sites Found in Veracruz, Mexico. URL: http://beforeitsnews. com/alternative/2013/07/2000-year-old-pyramid-and-multiple-pre-columbian-burial-sites-found-in-veracruz-mexico-2708338. html (date of access: June 25, 2014).

2. Coe, M. Maya. Vanished Civilization: Legends and Facts. Moscow, 2001. $270 \mathrm{p}$.

3. Gulyaev, V. City-States of the Maya (Structure and functions of the city in the early class society). Moscow: Nauka, 1979. 188 p.
4. Proskuryakova, T. Maya History. Austin: University of Texas Press, 1993. 240 p.

5. Rodríguez Martínez, Ma. Del Carmen, Ponciano Ortíz Ceballos, Michael D. Coe, Richard A. Diehl, Stephen D. Houston, Karl A. Taube and Alfredo Delgado Calderón. Oldest Writing in the New World. Science. September 16, 2006. Washington. Pp. 1610-1614.
СВЕДЕНИЯ ОБ АВТОРЕ:

\section{Зубарев Валентин Алексеевич}

аспирант

Белгородский государственный национальный исследовательский университет

ул. Победы, 85, г. Белгород, 308015, Россия E-mail: vazemus@mail.ru

\section{DATA ABOUT THE AUTOR:}

\section{Zubarev Valentin Alekseevich}

Postgraduate Student

Belgorod National Research University 85, Pobedy St., Belgorod, 308015, Russia E-mail: vazemus@mail.ru 